Pesq. Vet. Bras. 29(11):913-918, novembro 2009

\title{
Experimental infection of rabbits with a recombinant bovine herpesvirus type 5 (BoHV-5) gl, gE and US9-negative ${ }^{1}$
}

\author{
Alessandra D’Avila Silva ${ }^{2,3}$, Ana Cláudia Franco ${ }^{4 *}$, Paulo Augusto Esteves ${ }^{5}$, \\ Fernando Rosado Spilki ${ }^{6}$ and Paulo Michel Roehe ${ }^{2,3,4}$
}

\begin{abstract}
Silva A.D., Franco A.C., Esteves P.A., Spilki F.R. \& Roehe P.M. 2009. Experimental infection of rabbits with a recombinant bovine herpesvirus type 5 (BoHV-5) gl, gE and US9-negative. Pesquisa Veterinária Brasileira 29(11):913-918. Instituto de Pesquisas Veterinárias Desidério Finamor, Fepagro Saúde Animal, Estrada Municipal do Conde 6000, Caixa Postal 47, Eldorado do Sul, RS 92990-000, Brazil. Email: anafranco.ufrgs@gmail.com

Bovine herpesvirus type 5 (BoHV-5) is a major cause of viral meningoencephalitis in cattle. The expression of different viral proteins has been associated with BoHV-5 neuropathogenesis. Among these, gl, gE and US9 have been considered essential for the production of neurological disease in infected animals. To evaluate the role of $\mathrm{gl}, \mathrm{gE}$ and US9 in neurovirulence, a recombinant from which the respective genes were deleted (BoHV-5 gl-/gE-/US9-) was constructed and inoculated in rabbits of two age groups (four and eight weeks-old). When the recombinant virus was inoculated through the paranasal sinuses of four weeks-old rabbits, neurological disease was observed and death was the outcome in 4 out of $13(30.7 \%)$ animals, whereas clinical signs and death were observed in $11 / 13(84.6 \%)$ of rabbits infected with the parental virus. In eight weeks-old rabbits, the BoHV-5 gl-/gE-/US9- did not induce clinically apparent disease and could not be reactivated after dexamethasone administration, whereas wild type BoHV-5 caused disease in 55.5\% of the animals and was reactivated. These findings reveal that the simultaneous deletion of $\mathrm{gl}, \mathrm{gE}$ and US9 genes did reduce but did not completely abolish the neurovirulence of BoHV-5 in rabbits, indicating that other viral genes may also play a role in the induction of neurological disease.
\end{abstract}

INDEX TERMS: Bovine herpesvirus type 5, BoHV-5 gl-/gE-/US9-; rabbits, neuropathogenesis.

RESUMO.- [Infecção experimental de coelhos com um recombinante do herpesvírus bovino tipo 5 defectivo na gl, gE e US9.] O herpesvírus bovino tipo 5 é uma das principais causas de meningoencefalite viral em bovinos.

\footnotetext{
${ }^{1}$ Received on June 20, 2009.

Accepted for publication on July 14, 2009.

2 Equipe de Virologia, Instituto de Pesquisas Veterinárias Desidério Finamor (CPVDF), Fepagro Saúde Animal, Estrada do Conde 6000, Cx.Postal 47, Eldorado do Sul, RS 92990-000, Brazil.

3 Programa de Pós-Graduação em Ciências Veterinárias (PPGCV), Universidade Federal do Rio Grande do Sul (UFRGS), Av. Bento Gonçalves 9090, Porto Alegre, RS 91540-000, Brazil.

4 Instituto de Ciências Básicas da Saúde, UFRGS, Rua Sarmento Leite 500, Porto Alegre, RS 90050-170. *Corresponding author: anafranco.ufrgs@gmail.com

${ }^{5}$ Embrapa Suínos e Aves, BR153 Km 110, Vila Tamanduá, Cx.Postal 21, Concórdia, SC 89700-000, Brazil.

${ }^{6}$ Instituto de Ciências da Saúde, Centro Universitário Feevale, Campus II, RS 239 no.2755, Novo Hamburgo, RS 93352-000, Brazil.
}

A expressão de diferentes proteínas virais tem sido associada à neuropatogenia do BoHV-5. Entre estas, a gl, gE e US9 têm sido consideradas essenciais para a indução de sinais neurológicos nos animais infectados. Para avaliar o papel das proteínas gl, gE e US9 na neurovirulência, construiu-se um recombinante no qual os genes que codificam estas proteínas foram deletados, denominado BoHV-5 gl-/gE-/US9-. Este vírus foi inoculado em coeIhos de idades diferentes (quatro e oito semanas de idade). Quando o vírus recombinante foi inoculado nos seios paranasais de coelhos de quatro semanas de idade, doença neurológica e morte foram observadas em 4 dos 13 $(30,7 \%)$ animais, enquanto que sinais clínicos e morte foram observados em 11/13 (84,6\%) dos coelhos infectados com o vírus parental. Em coelhos de oito semanas de idade, o BoHV-5 gl-/gE-/US9- não induziu sinais clínicos aparentes e, após tentativa de reativação viral por tratamento com dexametasona, o vírus não foi re-excretado. 
Por outro lado, o vírus selvagem causou doença clínica em $55,5 \%$ dos coelhos e foi re-excretado após tratamento com dexametasona. Estes achados revelam que a deleção simultânea dos genes gl, gE e US9 reduziu mas não aboliu completamente a neurovirulência do BoHV-5 em coelhos, indicando que outros genes virais possam ter papel na indução da doença neurológica.

TERMOS DE INDEXAÇÃO: Herpesvírus bovino tipo 5, BoHV-5 $\mathrm{gl}^{\prime} / \mathrm{gE}-/ \mathrm{US9}^{-}$, coelhos, neuropatogênese.

\section{INTRODUCTION}

Bovine herpesvirus type 5 (BoHV-5), a member of the family Herpesviridae, subfamily Alphaherpesvirinae, is responsible for a fatal non-suppurative meningoencephalitis in cattle (Schudel et al. 1986). Like other alphaherpesviruses, BoHV5 is able to establish a lifelong latent infection in sensory ganglia of infected animals (Caron et al. 2002). The virus is endemic, at least in Brazil and Argentina, where severe outbreaks of neurological disease caused by BoHV- 5 have been reported (Carrillo et al. 1983, Schudel et al. 1986, Salvador et al. 1998, Gomes et al. 2002).

Several viral proteins seem to contribute to the neurovirulence of alphaherpesviruses (Chowdhury et al. 2000, Mettenleiter 2003). Glycoprotein E (gE) is a nonessential glycoprotein which is predominantly found complexed with glycoprotein I (gl) in alphaherpesviruses (Dingwell et al. 1995). In human herpesvirus type 1 (HHV1) the $\mathrm{gl} / \mathrm{gE}$ complex facilitates the in vitro cell-to-cell spread in epithelial cells as well as in neurons (Dingwell et al. 1995, Dingwell \& Johnson 1998). The lack of the gl/ gE complex in suid herpesvirus type I (SuHV-1), a neurovirulent alphaherpesvirus, impairs significantly the anterograde transport of the virus in axons, limiting its spread in the central nervous system (CNS), thereby reducing its neurovirulence (Enquist et al. 1999, 2002). The $\mathrm{gE}$ of bovine herpesvirus type 1 (BoHV-1) is important for the anterograde transport in neurons and a $g E$ cytoplasmic tail-truncated virus was significantly attenuated in experimental infections of rabbits (Liu et al. 2008). In addition, US9 was essential for reactivation of the BoHV1 in the trigeminal ganglia (TG) and anterograde axonal transport from TG to nose and eye (Butchi et al. 2007). The pathogenicity of BoHV-5 with either gE or US9 negative recombinants has been previously evaluated. In an experimental infection of rabbits with a BoHV-5 gE negative recombinant, the virus dissemination in CNS and induction of neurological signs were significantly impaired (Chowdhury et al. 2000). In addition, also for BoHV-5, US9 was shown to play an important role in viral transport from the olfactory receptor neurons to second order neurons within the olfactory bulb of rabbits, and a US9 negative BoHV-5 recombinant was virtually nonpathogenic and failed to invade the CNS (Chowdhury et al. 2002).

Aiming at the the development of an apathogenic BoHV5 with an impaired ability to reactivate from latent infections, we constructed a recombinant BoHV-5 from which genes gl, gE and US9 (gl-/gE-/US9-) were deleted (Franco et al. 2007). In order to examine the effect of a triple deletion of $\mathrm{gl}, \mathrm{gE}$ and US9 genes in neurovirulence, we inoculated rabbits of four and eight weeks-old with either the recombinant or the wild type viruses. We investigated the outcome of the acute infection and the potential of this recombinant to reactivate from latently infected animals.

\section{MATERIALS AND METHODS}

\section{Viruses and cells}

Madin-Darby bovine kidney cells (MDBK), originally from ATTC (CCL 22), were grown in Eagle's Minimal Essential Medium (E-MEM) supplemented with $6 \%$ fetal bovine serum (FBS) and $10 \mathrm{mg} / \mathrm{mL}$ enrofloxacin (Baytril). Cells and sera were tested periodically to ensure freedom of BoHV and bovine viral diarrhea virus (BVDV) contamination.

The BoHV-5 strain EVI 88/95 was isolated from a calf during an outbreak of meningoencephalitis in the state of Mato Grosso do Sul, Brazil, in 1995. This isolate has been characterized previously (Roehe et al. 1997, D'Arce et al. 2002, Souza et al. 2002). This virus was used for the construction of the BoHV-5 $\mathrm{gl}^{\prime} / \mathrm{gE} /$ /US9- recombinant (Franco et al. 2007). It was also used in the experiments with rabbits and in the neutralization tests.

\section{Design of the animal experiments}

Rabbits of a mixed breed were kept in isolation cages supplied with food and water ad libitum. Before infection rabbits were anesthesized with $2 \mathrm{mg}$ of tiletamine/zolazepam (Zoletil, Virbac) and inoculated into each paranasal sinuses with a total volume of $0.5 \mathrm{~mL}$ as described previously (Brown \& Field. 1990, Silva et al. 1999).

The first experiment was carried out to examine the pathogenicity of the recombinant BoHV-5 in four weeks-old rabbits. The animals were divided in three groups $(A, B, C)$ of 13 rabbits each. In group $A$, rabbits were inoculated with $10^{7.8} \mathrm{X}$ $50 \%$ tissue culture infective doses $/ \mathrm{mL}\left(\mathrm{TCID}_{50} / \mathrm{mL}\right)$ of the recombinant BoHV-5 gl//gE-/US9-. Rabbits of group B were inoculated with $10^{7.3} \mathrm{TCID}_{50} / \mathrm{mL}$ of wild type BoHV-5 strain EVI 88/95. In group C, 13 control rabbits were mock infected with $0.5 \mathrm{~mL}$ of sterile E-MEM.

A second experiment was performed to investigate the pathogenicity and ability of virus reactivation in eight weeks-old rabbits. The rabbits were divided into three groups (D, E and $F$ ). Group D consisted of 10 animals, which were inoculated with $10^{8.0} \mathrm{TCID}_{50} / \mathrm{mL}$ of the recombinant BoHV $-5 \mathrm{gl}^{-} / \mathrm{gE}-/ \mathrm{US} 9-$ Group $E$ consisted of 9 rabbits inoculated with $10^{8.0} \mathrm{TCID}_{50} / \mathrm{mL}$ of the wild type BoHV-5 strain EVI 88/95. Group F consisted of 10 negative control rabbits, mock infected with sterile E-MEM. From days 60 to 65 post-infection (pi), rabbits were submitted to five daily administrations of $2.6 \mathrm{mg} / \mathrm{kg}$ of dexamethasone (Dx; Schering-Plough) (Caron et al. 2002). On day 80 pi, all animals were culled and samples were collected for further processing. All procedures of animal care, handling and experimentation were performed under veterinary supervision and according to recommendations of the Brazilian College on Animal Experimentation (COBEA; http://www.cobea.org.br) and Brazilian law no. 6.638 of May 8, 1979.

\section{Clinical evaluation}

The rabbits were observed three times a day in search for clinical signs throughout the experiments. Clinical investigations 
included weighting (once daily), measurement of rectal temperature, observation of sneezing, coughing, nasal and/or ocular secretions, signs of depression (reduced appetite, apathy) and signs of neurological impairment (excitabilility or depression, tremors, bruxism, walking or running in circles, backward and sideways falling and paddling).

\section{Nasal virus spread}

In the first experiment, nasal swabs were collected daily from days 0 to 15 pi. In the second experiment, nasal swabs were collected daily from days 0 to 16 pi and from days 60 to 80 postreactivation (pr). The swabs were immersed in $1 \mathrm{~mL}$ of sterile $\mathrm{E}$ MEM supplemented with $200 \mathrm{U} / \mathrm{mL}$ penicillin, $200 \mu \mathrm{g} / \mathrm{mL}$ streptomycin and $5 \mu \mathrm{g} / \mathrm{mL}$ amphotericin B. Samples were stored at $-70^{\circ} \mathrm{C}$ until processing. Infectious virus titres were determined after inoculation of the samples on MDBK cells by the SpearmanKärber method. The identification of BoHV-5 infected cells was performed by immunostaining using a BoHV-5-specific monoclonal antibody as described previously (Kramps et al., 1994).

\section{Virus isolation}

Lung and brain samples (olfactory bulbs, anterior and posterior cortices, diencephalon, cerebellum and pons) were submitted to virus isolation by standard methods (Kaashoek et al. 1994). Infected cell cultures were monitored for the presence of virus up to 7 days after inoculation. Negative cultures were frozen at $-70^{\circ} \mathrm{C}$, thawed and submitted to one more passage. When viral cytopathogenic effect (CPE) was observed, the original tissue suspensions were titrated on MDBK cells. To confirm the identity of the recovered viruses, immunoperoxidase was performed as previously described (Kramps et al., 1994).

\section{Virus neutralization}

Serum samples were collected on days $0,7,14,21,28,35$, $42,49 \mathrm{pi}$, from four weeks-old rabbits and on days $0,7,14,21$, $30,45,60,75,80$ pi from eight weeks-old rabbits. Alternatively, serum samples were collected in extremis. Neutralizing antibodies on inactivated serum samples were determined in a varying serum-constant virus-neutralization (VN) assay on MDBK cell monolayers, with twofold dilutions of serum against 100 TCID $_{50}$ of BoHV-5 (House \& Baker 1971). Antibody titres were expressed as the reciprocal of the highest serum dilution that prevented the induction of CPE after 5 days of incubation. The geometric mean titres of each group of animals were calculated (Thrusfield 1986).

\section{Histopathology}

Tissues for histological examination were fixed in $10 \%$ buffered formalin, embedded in paraffin, sectioned at $6 \mathrm{~mm}$ and stained with haematoxylin-eosin (H\&E) following routine protocols (Prophet et al. 1992).

\section{Statistical analysis}

Statistical analyses were carried out using ANOVA by comparing the mean results for each group, taken daily. The calculation was made using Data Supplement Analysis Tool for Excel (Microsoft Office XP, Microsoft, USA), for $p<0.05$.

\section{RESULTS}

\section{Experimental infection of four weeks-old rabbits}

In the first experiment, with four weeks-old rabbits, 4/ $13(30.7 \%)$ rabbits inoculated with the recombinant BoHV$5 \mathrm{gl} / \mathrm{gE}$-/US9 (group A) died between days 7 and $18 \mathrm{pi}$. These animals displayed spastic paralysis, opisthotonus and coma. Histological examination of the brains of such rabbits evidenced mild meningoencephalitis. Infectious virus was detected in nasal secretions from 7/13 rabbits inoculated with the recombinant BoHV-5 between days 5 and 13 pi (Table 1). Infectious virus was found in the brain up to $10^{1.8} \mathrm{TCID}_{50} / \mathrm{g}$ (only after the second passage) in the diencephalon and trigeminal ganglia (Table 2), but it was not isolated from other regions of the CNS or lungs.

In rabbits inoculated with wild type BoHV-5 (group B), $11 / 13$ rabbits $(84.7 \%)$ died between days 7 and 9 pi after showing signs of excitability/depression, seizures, tremors, bruxism, opisthotonus, rear limb paralyses and severe depression. These rabbits revealed a moderate to severe meningoencephalitis upon histological examination. All rabbits in this group shed virus from days 4 to 10 pi from

Table 1. Summary of virus shedding, neurological disease and mortality in four weeks-old (groups A, B and C) and eight weeks-old (groups D, E and F) rabbits inoculated with the recombinant $\mathrm{BoHV}^{-5} \mathrm{gl}^{-} / \mathrm{gE}^{-} /$ US9- and wild type virus

\begin{tabular}{|c|c|c|c|c|c|c|c|c|c|}
\hline \multirow[t]{2}{*}{ Group } & \multirow[t]{2}{*}{ Virus } & \multirow{2}{*}{$\begin{array}{c}\text { Infectious } \\
\text { virus titres } \\
\text { of the } \\
\text { inoculum } \\
\text { (TCID50/mL) }\end{array}$} & \multirow{2}{*}{$\begin{array}{l}\text { Clinical } \\
\text { disease }\end{array}$} & \multirow{2}{*}{$\begin{array}{l}\text { Mortality } \\
(\%)\end{array}$} & \multicolumn{5}{|c|}{ Virus shedding } \\
\hline & & & & & $\begin{array}{l}\text { Start } \\
\text { (dpi) }^{\mathrm{C}}\end{array}$ & $\begin{array}{c}\text { Duration } \\
\text { (days) }\end{array}$ & $\begin{array}{l}\text { Infectious } \\
\text { virus titres } \\
\text { during acute } \\
\text { infection } \\
\text { (min-max) } \\
\text { (TCID50/mL) }\end{array}$ & $\begin{array}{c}\text { Infectious } \\
\text { virus titre at } \\
\text { attempted } \\
\text { reactivation } \\
(\text { min-max) } \\
\text { (TCID50/ml) }\end{array}$ & $\begin{array}{l}\text { Number of } \\
\text { animals } \\
\text { that } \\
\text { excreted } \\
\text { virus }\end{array}$ \\
\hline A & $\begin{array}{c}\text { BHV-5 } \\
\text { gl-/gE-/US9- }\end{array}$ & $10^{7.8}$ & $4 / 13^{a}$ & $4 / 13(30.7)$ & 5 & $9(5-13)$ & $1.55-1.8$ & - & $7 / 13$ \\
\hline B & Wild type virus & $10^{7.3}$ & $13 / 13$ & $11 / 13(84.7)$ & 4 & $7(4-10)$ & $1.55-2.05$ & - & $13 / 13$ \\
\hline $\mathrm{C}$ & Control & NA & $0 / 13$ & $0 / 13(0)$ & $N A^{d}$ & NA & $-e^{-0.00}$ & - & $0 / 1$ \\
\hline $\mathrm{D}$ & $\begin{array}{c}\text { BHV-5 } \\
\text { gl-/gE-/US9- }\end{array}$ & $10^{8.0}$ & $0 / 10$ & $0 / 10(0)$ & 5 & 6 & $1.55-2.05$ & - & $7 / 10$ \\
\hline E & Wild type virus & $10^{8.0}$ & $5 / 9$ & $5 / 9(55.5)$ & 4 & 9 & $1.55-2.05$ & $1.55-1.8$ & $8 / 9$ \\
\hline $\mathrm{F}$ & Control & NA & $0 / 10$ & $0 / 10(0)$ & NA & NA & - & - & $0 / 10$ \\
\hline
\end{tabular}

\footnotetext{
a Number of ill rabbits /total number of animals in the group; ${ }^{b}$ Number of dead rabbits/total of animals per group; ${ }^{C}$ Days postinfection; ${ }^{d}$ NA: not applicable; ${ }^{e}$ - negative.
} 
Table 2. Virus isolation from different regions of brain and from lungs of four weeks-old rabbits inoculated with either the recombinant BoHV-5 gl//gE-/US9- or wild type BoHV-5 virus (strain EVI 88/95)

\begin{tabular}{|c|c|c|c|c|c|c|c|c|c|}
\hline & \multicolumn{4}{|c|}{ Rabbit } & \multicolumn{5}{|c|}{ Infectious virus titres in: } \\
\hline & no. & $\begin{array}{l}\text { Olfactory } \\
\text { bulb }\end{array}$ & $\begin{array}{c}\text { Anterior } \\
\text { cortex }\end{array}$ & $\begin{array}{c}\text { Posterior } \\
\text { cortex }\end{array}$ & Cerebellum & Pons & Diencephalon & $\begin{array}{l}\text { Trigeminal } \\
\text { ganglion }\end{array}$ & Lung \\
\hline BoHV-5 & 1 & $-a$ & - & - & - & - & + & + & - \\
\hline \multirow[t]{3}{*}{$\mathrm{gl}^{-} / \mathrm{gE}-/ \mathrm{US}^{-}$} & 2 & - & - & - & - & - & + & - & - \\
\hline & 3 & - & - & - & - & - & + & - & - \\
\hline & 4 & - & - & - & - & - & + & + & - \\
\hline \multirow[t]{11}{*}{ Evi 88/95 } & 1 & + & +++ & +++ & + & + & + & + & + \\
\hline & 2 & + & ++ & +++ & ++ & + & ++ & + & - \\
\hline & 3 & ++ & ++ & ++ & + & + & + & + & - \\
\hline & 4 & + & +++ & ++++ & ++ & ++ & ++ & + & + \\
\hline & 5 & ++ & + & +++ & + & ++ & ++ & + & + \\
\hline & 6 & + & ++++ & +++ & + & + & + & + & + \\
\hline & 7 & + & ++ & +++ & ++ & ++ & ++ & + & + \\
\hline & 8 & + & +++ & +++ & +++ & +++ & ++ & + & + \\
\hline & 9 & ++ & ++ & ++ & +++ & +++ & ++ & + & + \\
\hline & 10 & +++ & +++ & ++ & ++++ & ++ & ++ & + & + \\
\hline & 11 & ++ & +++ & ++ & ++++ & +++ & ++ & + & + \\
\hline
\end{tabular}

nasal secretions (Table 1). Infectious virus was recovered from all regions of the brain, from trigeminal ganglia and lungs (Table 2). The rabbits of the negative control group remained healthy, did not shed virus in nasal secretions and remained BoHV-5 seronegative throughout the experiment.

\section{Experimental infection of eight weeks-old rabbits}

None of the animals inoculated with the recombinant virus (group D) showed detectable neurological signs. However, infectious virus was recovered from nasal secretions between days 5 to 10 pi in $7 / 10$ rabbits from group D.

In group E (inoculated with wild type BoHV-5), 55\% (5/ 9 rabbits) developed neurological signs and died; infectious virus was detected in brain tissues. Infectious virus was recovered from nasal secretions from day 4 to 12 pi in $8 / 9$ rabbits (Table 1). Under microscopic examination, non suppurative meningoencephalitis was observed in the brain sections of these animals. It was possible to isolate infectious virus from the lungs of 9 rabbits (Table 2). The rabbits in the control group (group F) remained healthy throughout the experiment.

To study virus reactivation from these animals, all the rabbits from groups $D$ and $F$, and those from group $E$ surviving acute infection, were submitted to dexamethasone (Dx) treatment from days 60 to $65 \mathrm{pi}$. The virological and clinical findings after Dx administration are summarized in Table 1. None of the rabbits in groups D, E or F showed detectable neurological signs. Virus shedding in nasal secretions could not be detected in rabbits previously inoculated with the recombinant virus (group D). On the other hand, rabbits inoculated with wild type BoHV-5 (group E) shed virus intermittently after the Dx treatment. No infectious virus could be recovered and no lesions were detected in tissues of rabbits inoculated with the recombinant BoHV-5 $\mathrm{gl}^{-} / \mathrm{gE}^{-} / \mathrm{US}^{-}$, or the wild type BoHV$5 \mathrm{EVI} 88 / 95$.

The neutralizing antibody responses of rabbits in group $D, E$ and $F$ are shown in Figure 1. The control group (F) was seronegative during the experiment, while the animals from groups $D$ and $E$ started to produce detectable antibodies from days 14 and 7 pi, respectively.

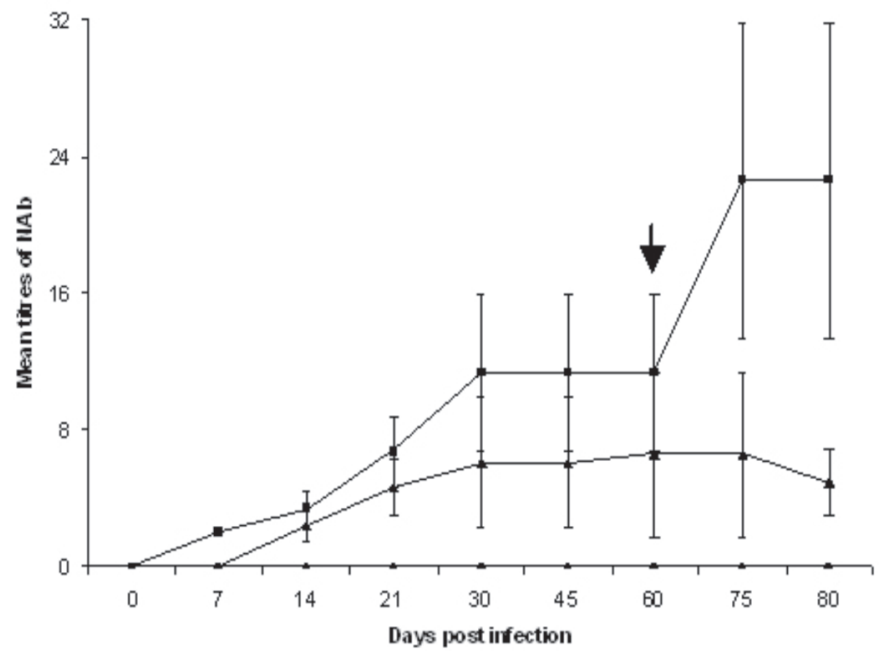

Fig.1. Geometric mean titres of neutralizing antibodies to BoHV5 of eight weeks-old infected rabbits. The black triangles refer to group D (animals infected with BoHV-5 $\mathrm{gl}^{-} / \mathrm{gE}^{-} / \mathrm{US9} 9^{-}$); the black squares refer to group $E$ (infected with the wild type virus EVI 88/95); the black circles refer to group $F$ (uninfected animals). Antibody titres are expressed as geometric mean titres of each group of animals on days postinfection. The bars indicate the standard deviations. The arrow indicates the day of dexamethasone administration (60 days post-infection). 


\section{DISCUSSION}

As gl, gE and US9 were previously reported to play a role in neurovirulence of BoHV-5 (Chowdhury et al. 2000, 2002), the present study was carried out to examine the neurovirulence and the potential for reactivation of a recombinant BoHV-5 lacking the gl, gE and US9 genes. When the recombinant BoHV-5 gl/ $/ \mathrm{gE}-/ \mathrm{US}^{-}$was inoculated intranasally in four weeks-old rabbits, it was less virulent than the wild type BoHV-5. One third of the rabbits inoculated with the recombinant developed neurological signs and died, whereas the wild type BoHV-5 induced neurological disease and killed about $90 \%$ of the infected animals. The recombinant virus was still able to reach the trigeminal ganglia and midbrain/diencephalon, but dissemination to other parts of the central nervous system (CNS) and lungs was impaired. In contrast, wild type BoHV-5 virus was isolated consistently (and to higher titres than the recombinant virus) from different regions of the brain and lungs. These results show that the spread of the recombinant virus in the CNS was limited but not totally blocked by the lack of these proteins. Similar results were obtained in an experimental infection of calves using the BoHV-5 $\mathrm{gl}^{-} / \mathrm{gE}^{-} /$ US9- virus (Hübner et al. 2005). Infectious virus, viral antigens and DNA were found in limited portions of the CNS of one out of six calves infected with the recombinant (Hübner et al. 2005). These results are in contrast with previous experiments performed with different $\mathrm{gE}$ and US9 BoHV-5 recombinants (Chowdhury et al. 2000, 2002). A BoHV-5 gE- recombinant was able to induce neurological signs in about $10 \%$ of the infected rabbits and no deaths, while the wild type virus caused apparent neurological disease in 70 to $80 \%$ of the infected animals. On that occasion, and contrasting with the findings presented herein, the $\mathrm{gE}^{-}$recombinant was not found in the CNS of infected rabbits (Chowdhury et al. 2000, 2002). In another experiment, a US9 negative BoHV-5 was virtually apathogenic, did not invade the CNS and caused no death when inoculated in rabbits (Chowdhury et al. 2000, 2002). We believe that differences in age and breed of the infected rabbits could not justify such discrepancies, since these were comparable in both experiments. On the other hand, differences between virus strains might be a relevant source of variation, since it has been shown that different BoHV-5 isolates may significantly differ in their neurovirulence (Silva et al. 1999, Beltrão et al. 2001, Spilki et al. 2002).

When inoculated in older animals, the recombinant virus was apathogenic, contrasting with the effect of the wild type virus infection (which caused death in $55.5 \%$ of infected animals). These results show a correlation between the age of the animals on the day of inoculation and the severity of the disease, what was already demonstrated (Beltrão et al. 2001, Caron et al. 2002).

Following Dx administration, neurological signs and virus isolation from brain sections of rabbits inoculated with the recombinant or with the wild type virus were investigated. The BoHV-5 gl//gE-/US9- recombinant could not be recovered from nasal secretions, whereas the wild type virus could indeed be recovered. The failure in detecting the recombinant virus in nasal secretions after Dx is probably related to an impaired anterograde axonal transport of virions, which is needed for the transport of reactivated viruses to the primary site of infection and is mediated by US9. This phenomenon had already been observed in previous experiments attempting to isolate US9- or gE/US9- recombinants of SuHV-1 or BoHV-1 from latently infected animals (Kaashoek et al. 1994, Enquist et al. 1999, 2002, Chowdhury et al. 2002). It has been shown that these recombinant viruses could not be reexcreted due to the lack of US9, which is essential for the anterograde transport of virions along the axons (Enquist et al. 1999, 2002, Butchi et al. 2007). Although virus reactivation did occur in rabbits inoculated with the wild type BoHV-5, those did not display clinical signs during the period of virus excretion.

Neutralizing antibodies were detected in sera from animals infected with both the wild type and recombinant BoHV-5 (Figure 1). The levels of neutralizing antibodies detected until day $60 \mathrm{pi}$, when the Dx treatment took place, were similar when groups $\mathrm{D}$ (infected with the recombinant) and $E$ (infected with the wild type) were compared. On days 75 and 80pi (or 15 and 20 pr) the levels of neutralizing antibodies from animals of group $D$ were significantly lower and showed a tendency to decrease when compared to animals from group $\mathrm{E}$. These lower antibodies levels in animals infected with the recombinant are probably related to a lack of reactivation and replication of the virus in nasal secretions following the Dx treatment. On the other hand, the increased levels of antibodies found in group $\mathrm{E}$ correspond to the period that they re-excreted virus, what probably boosted their immune response.

The aim of this study was to examine the neurovirulence and reactivation potential of a recombinant BoHV- 5 with deletions of the gl, gE and US9 genes using rabbits as models. Under the conditions of this study, the recombinant virus could still induce neurological signs in four weeksold rabbits, but was apathogenic for eight weeks-old rabbits. After Dx administration, the recombinant virus did not induce neurological signs in rabbits nor was excreted in nasal secretions. In view of these findings, it can be concluded that the BoHV-5 $\mathrm{gl}^{-} / \mathrm{gE}^{-} / \mathrm{US9}^{-}$replicates efficiently, induces a detectable immune response and shows a reduced virulence in rabbits. It is conceivable that additional deletions in the viral genome are needed as to completely abolish its neurovirulence.

Acknowledgements.- A.D. Silva and P.A. Esteves were students from the Programa de Pós-Graduação em Ciências Veterinárias, Faculdade de Veterinária (PPGCV/UFRGS/Brazil), grantees of CAPES. P.M. Roehe is a CNPq research fellow. We thank N.C. Rodrigues for the histopathological analyses. This study was supported by CNPq Pronex, FAPERGS and CAPES.

\section{REFERENCES}

Beltrão N., Flores E.F., Weiblen R., Silva A.M., Roehe P.M. \& Irigoyen L.F. 2001. Infecção e enfermidade neurológica pelo herpesvírus bo- 
vino tipo 5 (BHV-5): coelhos como modelo experimental. Pesq. Vet. Bras. 20:144-150.

Brown G.A. \& Field H.J. 1990. Experimental reactivation of bovine herpesvirus (BHV-1) by means of corticosteroids in intranasal rabbits models. Arch. Virol. 112:81-101.

Butchi N.B., Jones C., Perez S., Doster A. \& Chowdhury SI. 2007. Envelope protein Us9 is required for the anterograde transport of bovine herpesvirus type 1 from trigeminal ganglia to nose and eye upon reactivation. J. Neurovirol. 13(4):384-388.

Caron L., Flores E.F., Weiblen R., Scherer C.F.C., Irigoyen L.F., Roehe P.M., Odeon A. \& Sur J.H. 2002. Latent infection by bovine herpesvirus type- 5 in experimentally infected rabbits: virus reactivation, shedding and recrudescence of neurological disease. Vet. Microbiol. 84(4):285-295.

Carrillo B.J., Ambrogi A., Schudel A.A., Vazquez M., Dahme E. \& Pospischil A. 1983. Meningoencephalitis caused by IBR virus in calves in Argentina. Zentralbl. Veterinärmed. B 30:327-332.

Chowdhury S.I., Lee B.J., Ozkul A. \& Weiss M.L. 2000. Bovine herpesvirus 5 glycoprotein $\mathrm{E}$ is important for neuroinvasiveness and neurovirulence in the olfactory pathway of the rabbit. J. Virol. 74::2094-2106.

Chowdhury S.I., Onderci M., Bhattacharjee P.S., Al-Mubarak A., Weiss M.L. \& Zhou Y. 2002. Bovine herpesvirus 5 (BHV-5) US9 is essential for BHV-5 neuropathogenesis. J. Virol. 76: 3839-3851.

D'Arce R.C.F., Almeida R.S., Silva T.C., Franco A.C., Spilki F.R., Roehe P.M. \& Arns C.W. 2002. Restriction endonuclease and monoclonal antibody analysis of Brasilian isolates of bovine herpesvirus types 1 and 5. Vet. Microbiol. 88:315-324.

Dingwell K.S., Doering L.C. \& Johnson DC. 1995. Glycoproteins E and I facilitate neuron-to-neuron spread of herpes simplex virus. J. Virol. 69(11):7087-7098.

Dingwell K.S. \& Johnson D.C. 1998. The herpes simplex virus gE-gl complex facilitates cell-to-cell spread and binds to components of cel junctions. J. Virol. 72:8933-8942.

Enquist L.W., Husak P.J., Banfield B.W. \& Smith G.A. 1999. Infection and spread of alphaherpesviruses in the nervous system. Adv. Virus Res. 51:237-347.

Enquist L.W., Tomishima M.J., Gross S. \& Smith G.A. 2002. Directional spread of an a-herpesvirus in the nervous system. Vet. Microbiol. 86:516.

Franco A.C., Hübner S.O., Oliveira A.P., Batista H.B., Roehe P.M. \& Rijsewijk F. 2007. Construction and characterization of a bovine herpesvirus 5 mutant with a deletion of the gl, gE and US9 genes. Braz. J. Microbiol. 38:667-673.

Gomes L.I., Rocha M.A., Costa E.A., Lobato Z.I.P., Mendes L.C.N., Borges A.S., Leite R.C. \& Barbosa-Stancioli E.F. 2002. Detecção de herpesvírus bovino 5 (BoHV-5) em bovinos do sudeste brasileiro. Arq. Bras. Med. Vet. Zoot. 54:217-220.
House J.A. \& Baker J.A. 1971. Bovine herpesvirus IBR-IPV. The antibody virus neutralization reaction. Cornell Vet. 61:320-335.

Hübner S., Oliveira A.P., Franco A.C., Esteves P.A., Spilki F.R., Rijsewijk F.A.M. \& Roehe P.M. 2005. Experimental infection of calves with a gl, gE, US9 negative bovine herpesvirus type 5. Comp. Immunol. Microbiol. Infect. Dis. 28:187-196.

Kaashoek M.J., Moerman A., Madic J., Rijsewijk F.A.M., Quak J. \& Gielkens A.L. 1994. A conventionally attenuated glycoprotein Enegative strain of bovine herpesvirus type 1 is an efficacious and safe vaccine. Vaccine 12:439-444.

Kramps J.A., Magdalena J., Quak J., Weerdmeester K., Kaashoek M.J., Maris-Veldhuis M.A., Rijsewijk F.A., Keil G. \& Van Oirschot J.T. 1994. A simple, specific, and highly sensitive blocking enzyme-linked immunosorbent assay for detection of antibodies to bovine herpesvirus 1. J. Clin. Microbiol. 32:2175-2181.

Liu Z.F., Brum M.C., Doster A., Jones C. \& Chowdhury S.I. 2008. A bovine herpesvirus type 1 mutant virus specifying a carboxyl-terminal truncation of glycoprotein $E$ is defective in anterograde neuronal transport in rabbits and calves. J. Virol. 82(15):7432-7442.

Mettenleiter T.C. 2003. Pathogenesis of neurotropic herpesviruses: role of viral glycoproteins in neuroinvasion and transneuronal spread. Virus Res: 92:197-206.

Prophet E.B., Mills B., Arrington J.B. \& Sobin L.H. 1992. Laboratory Methods in Histotechnology. Armed Forces Institute of Pathology, Washington, DC

Roehe P.M., Silva T.C., Nardi N.B., Oliveira D.G. \& Rosa J.C.A. 1997. Diferenciação entre o vírus da rinotraqueíte infecciosa bovina (BHV1) e o vírus da encefalite bovina (BHV-5). Pesq. Vet. Bras. 17:41-44.

Schudel A.A., Carrillo B.J., Wyler R. \& Metzler A.E. 1986. Infections of calves with antigenic variants of bovine herpesvirus 1 (BHV-1) and neurological disease. Zentralbl. Veterinärmed. B 33:303-310.

Silva A.M., Flores E.F., Weiblen R., Canto M.C., Irigoyen L.F., Roehe P.M. \& Souza R. 1999. Pathogenesis of meningoencephalitis in rabbits by bovine herpesvirus type 5 (BHV-5). Revta Microbiol. 30:22-31.

Souza V.F., Melo S.V., Esteves P.A., Schmidt C.S., Gonçalves D.A., Schaefer R., Silva T.C., Almeida R.S., Vicentini F., Franco A.C., Oliveira E.A., Spilki F.R., Weiblen R., Flores E.F., Lemos R.A., Alfieri A.A., Pituco E.M. \& Roehe, P.M. 2002. Caracterização de herpesvírus bovinos tipos 1 (BHV-1) e 5 (BHV-5) com anticorpos monoclonais. Pesq. Vet. Bras. 22:13-18.

Spilki F.R., Esteves P.A., Franco A.C., Lima M., Holz C., Batista H.B.R., Driemeier D., Flores E.F., Weiblen R. \& Roehe P.M. 2002. Neurovirulência e neuroinvasividade de herpesvírus bovinos tipos 1 e 5 em coelhos. Pesq. Vet. Bras. 22:58-63.

Thrusfield M. 1986. Veterinary Epidemiology. Chap 16: Serological epidemiology. Butterworth, London, p.175-185. 